\title{
RAND Experts Available on Afghanistan Presidential Election
}

\author{
April 2, 2014
}

RAND Corporation experts are available to discuss a variety of issues related to Saturday's election in Afghanistan, in which voters will select the second democratically elected leader in the nation's history. Among the topics they can address:

- Who are the candidates? Who is likely to win? What are the implications should there be a run-off?

- How might regional variations and ethnic tensions influence the final outcome?

- What tactics might the Taliban use to hinder the election?

- Could election fraud be a major issue?

- What is the legacy of current president Hamid Karzai?

- Does the United States have an interest in one candidate over the others? What is the impact of the election on the U.S.-Afghanistan bilateral security agreement?

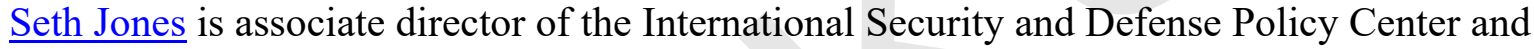
advisor to the U.S. Special Operations Command on Afghanistan and Pakistan. He authored "Presidential Candidates Need Multiethnic Consensus" and "Hunting in the Shadows: The Pursuit of Al Qa'ida Since 9/11."

Paul D. Miller is a political scientist, former director for Afghanistan and Pakistan on the National Security Council staff, and former Afghanistan analyst at the Central Intelligence Agency. He authored the just-published study, "Democracy in Afghanistan: The 2014 Election and Beyond."

Jonah Blank is a senior political scientist who served as the former policy director for South and Southeast Asia on the staff of the Senate Foreign Relations Committee. A specialist on Afghanistan-Pakistan relations, he authored the commentary, "How to Negotiate Like a Pashtun."

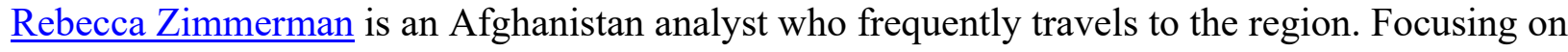
special operations and issues of governance and development, Zimmerman authored the commentary, "Stuck Between a Rock and a 'Zero Option'" and "The Death of a Butterfly in Kabul."

Jason Campbell is an associate policy analyst focusing on reconciliation and reintegration efforts in Afghanistan and the development of the Afghan national security forces. He authored the commentary, "The Pernicious Effects of Uncertainty in Afghanistan." Campbell recently returned from Afghanistan.

\section{Interviews}


To arrange an interview, contact the RAND Office of Media Relations: (703) 414-4795 or

(310) 451-6913, or send an email to media@,rand.org. 